\title{
COMPETITION INDICES FOR WHEAT AND FABA BEAN INTERCROPPED TOGETHER UNDER SANDY SOIL CONDITIONS.
}

\author{
(Received:5 .5. 2011)
}

\author{
By \\ M.S.S. Badran \\ Department of Crop Science, Faculty of Agriculture, Damanhour University, Egypt
}

\begin{abstract}
Egyptian faba bean cultivar Sakha 1 was planted either solely or intercropped with four Egyptian wheat varieties i.e., Giza 168, Sakha 94, Gemmiza 9 and Sids 1 by seven cropping patterns. The cropping patterns i.e., sowing wheat at three seeding rates $\left(300,350\right.$ and 400 grains $\left./ \mathrm{m}^{2}\right)$ solely and intercropped with faba bean as well as solid faba bean plantings, were tested for each wheat variety in alternative rows 20 $\mathrm{cm}$ apart (1:1). The main objective of this work was to determine the suitable (wheat /faba bean) intercropping treatment for maximizing the land productivity of sandy soil through calculating the degree of competition indices for both crops. Hence, both faba bean seed yield and wheat grain yield tons/ ha were used to calculate the degrees of competition indices in terms of Land Equivalent Ratio (LER), Aggressivity (Ag) and Relative Crowding Coefficient (RCC). Two field experiments were carried out at the Experimental Station Farm of the Faculty of Agriculture, Damanhour University, El-Bostan Region, El- Behera Governorate, Egypt, during 2009/2010 and 2010/2011 seasons. A split-plot design with four replicates was used in both seasons. Wheat varieties were randomly assigned to the main-plots, while intercropping patterns were allocated in the sub-plots. The obtained results can be summarized as follows:

- LER was insignificantly affected by the four studied wheat varieties in both seasons. Meanwhile, the intercropping patterns significantly affected LER values, in both seasons. LER values averaged of both seasons were greater than one (1.40) for intercropping plantings.

- Values of aggressivity of wheat varieties were significantly differed in the second season only. Sakha 94 was the most aggressive wheat variety compared with the other studied varieties in both seasons. The data also, revealed that the aggressivity values of faba bean were positive, while that of wheat was negative, under intercropping treatments in both seasons.

- RCC for wheat and faba bean was insignificantly affected among wheat varieties, in both seasons. The higher values of $\mathrm{RCC}_{\mathrm{w}}$ were produced when using Giza 168 (wheat variety) meanwhile, the lowest $\mathrm{RCC}_{\mathrm{f}}$ values were produced by Sids 1 variety in both seasons.

A significant interaction was detected between wheat varieties and cropping patterns $\left(\mathrm{Vx}_{1}\right)$ for the relative yield of wheat, in the first season only.

In general, it could be concluded that intercropping any studied wheat variety with seeding rate of 300 grains $/ \mathrm{m}^{2}$ with Sakha 1 faba bean cultivar at 166667 plants/ ha in alternative rows $20 \mathrm{~cm}$ apart $(1: 1)$ could be recommended to maximizing the productivity of land unit area under sandy soil conditions, in El-Bostan Region, El- Behera Governorate, Egypt.
\end{abstract}

Key words: aggressivity, faba bean, intercropping patterns, land equivalent ratio, relative crowding coefficient, wheat varieties.

\section{INTRODUCTION}

The intercropping crops compete for different below and above soil environmental factors. Intercropping legume crop with non-legume one proved to be a successful system owing to the ability of legume to fix considerable non-legume (El-Metwally et al., 2002). Many researches reported that land use efficiency was increased and yield advantage was produced by intercropping faba bean with wheat (Ali et al., 1986; Saleh et al., 1986; Abd El-Gawad et al., 1988 and El-Metwally et al., 2002). Saleh et al. (1986) stated that growing wheat and faba bean in 2:2 intercropping system increased land usage by about 90\%. Eid et al. (1988) reported that the intercropping wheat with faba bean in 1:1 pattern 
gave the maximum values of (LER) and (RCC). El-Metwally et al. (2002) intercropped wheat and faba bean under different systems. They found that LER was increased by $91 \%$ over the monoculture in 2:2 pattern. Also, intercropping pattern, 2:2 produced the highest RCC (618.89), while the highest value for Aggressivity ( $\mathrm{Ag}$ ) was obtained from 3:3 pattern. Therefore, measuring the degree of competition relationships in terms of LER, Ag and RCC for intercropping wheat with faba bean using different wheat varieties and cropping patterns to determine the best suitable (wheat /faba bean) combination treatment for maximizing the land productivity under sandy soil conditions was the aim of this investigation.

\section{MATERIALS AND METHODS}

Two field experiments were carried out in two successive winter seasons of 2009/2010 and 2010/2011 at the Experimental Farm of the Faculty of Agriculture, Damanhour University, El-Bostan region, El- Behera Governorate, Egypt. The main objective of this work was to study the effect of four Egyptian wheat varieties (Giza 168, Sakha 94, Gemmiza 9 and Sids 1) in seven cropping patterns of wheat and faba bean on the competition indices of wheat and faba bean to determine the best intercropping treatment to maximize the productivity of unit area in sandy soil conditions.

The seven cropping patterns were as follows:

1-Sole wheat plantings at a rate of 300 grain $/ \mathrm{m}^{2}$ $\left(\mathrm{W}_{\mathrm{L}} \mathrm{F}_{0}\right)$.

2- Sole wheat plantings at a rate of 350 grain $/ \mathrm{m}^{2}$ $\left(\mathrm{W}_{\mathrm{m}} \mathrm{F}_{0}\right)$.

3- Sole wheat plantings at a rate of 400 grain $/ \mathrm{m}^{2}$ $\left(\mathrm{W}_{\mathrm{h}} \mathrm{F}_{0}\right)$.

4-Intercropped wheat with faba bean at a rate of 300 grain of wheat $/ \mathrm{m}^{2}\left(\mathrm{~W}_{\mathrm{L}} \mathrm{F}_{1}\right)$.

5-Intercropped wheat with faba bean at a rate of 350 grain of wheat $/ \mathrm{m}^{2}\left(\mathrm{~W}_{\mathrm{m}} \mathrm{F}_{1}\right)$.

6-Intercropped wheat with faba bean at a rate of 400 grain of wheat $/ \mathrm{m}^{2}\left(\mathrm{~W}_{\mathrm{h}} \mathrm{F}_{1}\right)$.

7- Sole faba bean plantings $\left(\mathrm{W}_{0} \mathrm{~F}_{1}\right)$.

Soil samples taken from the experimental sites were analyzed mechanically (Piper, 1950) and their characteristics are presented in Table (1).The area of sub-plots was $7.0 \mathrm{~m}^{2}(3.5 \mathrm{~m}$ length and $2.0 \mathrm{~m}$ width) included 10 rows, $20 \mathrm{~cm}$ apart , where wheat seeds were hand drilled, while faba bean was hand planted in hills, in both seasons. Faba bean (Sakha 1 cultivar) intercropped with wheat in alternate rows $(1: 1)$. The plant population of faba bean was about 166667 plants/ ha. The respective plant population was maintained through thinning seedlings to one plant/ hill, spaced at 30 and $15 \mathrm{~cm}$ for solid and intercropping

Table (1): Soil mechanical analysis of the experimental sites at El-Bostan region during 2009/2010 and 2010/2011 seasons.

\begin{tabular}{|c|c|c|}
\hline \multirow{2}{*}{ Characteristic } & \multicolumn{2}{|c|}{ Season } \\
\cline { 2 - 3 } & $2009 / 2010$ & $02010 / 2011$ \\
\hline Sand (\%) & 77.37 & 74.25 \\
\hline Silt (\%) & 4.66 & 5.11 \\
\hline Clay (\%) & 17.97 & 20.64 \\
\hline Texture class & \multicolumn{2}{|c|}{ Sandy } \\
\hline
\end{tabular}

treatments, respectively. Both crops were sown on the $5^{\text {th }}$ of Nov. in both seasons. Phosphorus fertilizer was broadcasted during soil preparation in the form of calcium super-phosphate

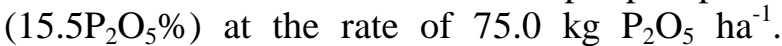
Potassium sulphate $\left(48 \% \mathrm{~K}_{2} \mathrm{O}\right)$ was dressed at the rate of $60.0 \mathrm{~kg} \mathrm{~K}_{2} \mathrm{O} \mathrm{ha}^{-1}$ before the first irrigation. Ammonium sulphate $(20.5 \% \mathrm{~N})$ at the rate of 240 $\mathrm{kg} \mathrm{N} / \mathrm{ha}$ was added in three portions (1/5) broadcasted after sowing before irrigation and $(4 / 5)$ was dressed at two equal doses before the $1^{\text {st }}$ and $2^{\text {nd }}$ irrigation. All other cultural practices were applied as usually recommended for wheat and faba bean fields in El-Bostan Region. Plants were harvested at maturity stage and at 155 days from sowing for faba bean and wheat, respectively, to determine the faba bean seed yield and wheat grain yield in tons/ha and used to calculate the following three competitive relations: 1-Land Equivalent Ratio (LER): was determined according to Willey's equation (1979), as follows:

$$
\begin{gathered}
\mathrm{RY}_{\mathrm{w}}=\mathrm{Y}_{\mathrm{iw}} / \mathrm{Y}_{\mathrm{ww}} \\
\mathrm{RY}_{\mathrm{f}}=\mathrm{Y}_{\mathrm{if}} / \mathrm{Y}_{\mathrm{ff}} \\
\mathrm{LER}=\mathrm{RY} \mathrm{w}_{\mathrm{w}}+\mathrm{RY}_{\mathrm{f}}
\end{gathered}
$$

Where:

$R Y_{w}=$ Relative yield of wheat.

$R Y_{f}=$ Relative yield of faba bean.

$Y_{\mathrm{iw}}=$ Intercrop yield of wheat.

$Y_{\text {if }}=$ Intercrop yield of faba bean.

$Y_{w w}=$ Solid crop yield of wheat.

$\mathrm{Y}_{\mathrm{ff}}=$ Solid crop yield of faba bean .

2- Aggressivity (Ag): It was calculated according to McGilchrist s (1965)

equation, as follows:

$$
\begin{aligned}
& A g_{w}=\left(Y_{i w} / Y_{w w}\right)-\left(Y_{i f} / Y_{f f}\right) . \\
& A g_{f}=\left(Y_{\text {if }} / Y_{f f}\right)-\left(Y_{i w} / Y_{w w}\right) .
\end{aligned}
$$


Table (3): Means of relative yields of wheat $\left(\mathrm{RY}_{\mathrm{w}}\right)$ as affected by different wheat varieties (V) and (wheat/ faba bean cropping patterns (I) in $2009 / 2010$ and 2010/2011 seasons.

\begin{tabular}{|c|c|c|c|c|c|c|c|c|c|c|c|c|c|c|c|}
\hline \multirow{3}{*}{ 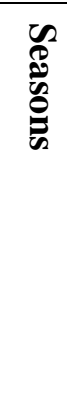 } & \multicolumn{4}{|c|}{ Wheat varieties (V) } & \multicolumn{10}{|c|}{ Comparisons among (wheat/ faba bean) cropping patterns (I) } & \multirow{3}{*}{$\frac{2}{3}$} \\
\hline & \multirow[t]{2}{*}{ Giza 168} & \multirow[t]{2}{*}{$\frac{\mathscr{0}}{\hat{x}^{2}}$} & \multirow[t]{2}{*}{ 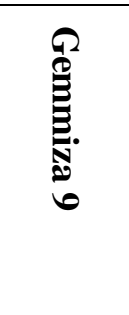 } & \multirow[t]{2}{*}{ Sids1 } & \multicolumn{2}{|c|}{$\begin{array}{c}\mathrm{C}_{1} \text { : Solid vs. } \\
\text { intercropping wheat } \\
\text { plantings }\end{array}$} & \multicolumn{2}{|c|}{$\begin{array}{c}\mathbf{C}_{2:}:\left\{\mathbf{W}_{\mathbf{L}} \mathbf{F}_{0} \text { vs. }\right. \\
\left(\mathbf{W}_{\mathbf{m}} \mathbf{F}_{\mathbf{0}} \text { and }\right. \\
\left.\left.\mathbf{W}_{\mathbf{h}} \mathbf{F}_{0}\right)\right\}\end{array}$} & \multicolumn{2}{|c|}{$\begin{array}{c}\mathbf{C}_{3}: \\
\left(\mathbf{W}_{\mathrm{m}} \mathbf{F}_{\mathbf{0}} \text { vs. } \mathbf{W}_{\mathrm{h}} \mathbf{F}_{0}\right)\end{array}$} & \multicolumn{2}{|c|}{$\begin{array}{c}\mathbf{C}_{4}: \\
\mathbf{W}_{\mathbf{L}} \mathbf{F}_{1} \text { vs. } \\
\left(\mathbf{W}_{\mathbf{m}} \mathbf{F}_{1} \text { and }\right. \\
\left.\mathbf{W}_{\mathbf{h}} \mathbf{F}_{1}\right)\end{array}$} & \multicolumn{2}{|c|}{$\begin{array}{c}\mathrm{C}_{5}: \\
\left(\mathrm{W}_{\mathrm{m}} \mathrm{F}_{1} \text { vs. } \mathrm{W}_{\mathrm{h}} \mathrm{F}_{1}\right)\end{array}$} & \\
\hline & & & & & Solid & Intercropping & $\mathbf{W}_{\mathbf{L}} \mathbf{F}_{\mathbf{0}}$ & $\begin{array}{c}\left(\mathbf{W}_{\mathbf{m}} \mathbf{F}_{0}\right. \\
\text { and } \\
\left.\mathbf{W}_{\mathbf{h}} \mathbf{F}_{\mathbf{0}}\right)\end{array}$ & $\mathbf{W}_{\mathrm{m}} \mathbf{F}_{\mathbf{0}}$ & $\mathbf{W}_{\mathbf{h}} \mathbf{F}_{\mathbf{0}}$ & $\mathbf{W}_{\mathbf{L}} \mathbf{F}_{1}$ & $\begin{array}{c}\left(\mathbf{W}_{\mathrm{m}} \mathbf{F}_{1}\right. \\
\text { and } \\
\mathbf{W}_{\mathrm{h}} \mathbf{F}_{1}\end{array}$ & $\mathbf{W}_{\mathrm{m}} \mathbf{F}_{1}$ & $\mathbf{W}_{\mathrm{h}} \mathbf{F}_{1}$ & \\
\hline $\mathbf{1}^{\text {st }}$ & $0.780 a^{(1)}$ & 0.690a & $0.762 a$ & 0.678a & $\mathbf{0 . 8 3 4 a}$ & $0.621 b$ & $0.765 b$ & $0.869 \mathrm{a}$ & 0.865a & 0.873a & $0.559 a$ & $0.632 \mathrm{a}$ & 0.646a & 0.619a & 0.728 \\
\hline $2^{\text {nd }}$ & 0.808a & $0.698 a$ & $0.763 a$ & $0.653 a$ & 0.841a & 0.620b & 0.739b & $0.892 a$ & 0.883a & $0.902 a$ & $0.568 a$ & 0.646a & $0.669 a$ & $0.624 a$ & 0.731 \\
\hline
\end{tabular}

(1) Means followed by the same letter within each row, for each comparison, are not significantly different at 0.05 level.

$\left(W_{L} F_{0} ; W_{m} F_{0}\right.$ and $\left.W_{h} F_{0}\right)=$ Sowing wheat as sole crop at rates of $\left(300,350\right.$ and 400 grains $\left./ \mathrm{m}^{2}\right)$, respectively.

$\left(W_{L} F_{1} ; W_{m} F_{1}\right.$ and $\left.W_{h} F_{1}\right)=$ Intercropped wheat with faba bean by seeding wheat of $\left(300,350\right.$ and 400 grains $\left./ \mathrm{m}^{2}\right)$, respectively. 
same $\left(R Y_{w}\right)$ means in both studied seasons (Tables 2 and 3$)$.

\subsubsection{Relative yield of faba bean $\left(R Y_{f}\right)$}

The variations among the studied wheat varieties did not reach the level of significance for Relative yield of faba bean $\left(\mathrm{RY}_{\mathrm{f}}\right)$, in both seasons (Table 4). Concerning the first comparison $\left(\mathrm{C}_{1}\right)$, Relative yield of faba bean $\left(R Y_{f}\right)$, in both seasons (Table 4). Concerning the first comparison $\left(C_{1}\right)$, faba bean solid plantings $v s$. faba bean intercropped with wheat, the data in Tables ( 4 and 5) showed that intercropping wheat with faba bean significantly decreased the Relative yield of faba bean $\left(R Y_{f}\right)$, in both seasons. These results might be expected, where low plant population for faba bean monoculture decreases the plant competition, thus leads to increase the ability of plants to uptake both soil water and nutrient elements with its good deeply roots and laterally distribution since there is a good balance between plant density and soil sources especially of the experimental farm soil which is sandy $(75.81 \%)$ and its often poor fertility level with verged to organic matter, macro and micronutrients. The above mentioned trend was true for the two comparisons i.e., $\left(\mathrm{C}_{2}\right)$ and $\left(\mathrm{C}_{3}\right)$, where intercropped faba bean with lower density of wheat increased values of Relative yield of faba bean $\left(\mathrm{RY}_{\mathrm{f}}\right)$ compared with the same treatment but under higher density of wheat (Table 5). These results can explain the basis of the lower wheat plant density under intercropping with faba bean which led to decrease the inter and intra specific competitions and favored more utilization of faba

Table (4): Mean squares of relative yields for faba bean $\left(R Y_{f}\right)$ intercropped with wheat in 2009/2010 and 2010/2011 seasons.

\begin{tabular}{|c|c|c|c|}
\hline \multirow[t]{2}{*}{ Sources of variation } & \multirow[t]{2}{*}{ D.F } & \multicolumn{2}{|c|}{ Season } \\
\hline & & $2009 / 10$ & $2010 / 11$ \\
\hline Replications & 3 & 0.026 & $0.074 *$ \\
\hline Wheat varieties $(\mathbf{V})$ & 3 & 0.002 & 0.031 \\
\hline Error "a" & 9 & 0.035 & 0.014 \\
\hline Cropping patterns (I) & 3 & $0.235 * *$ & $0.305 * *$ \\
\hline$+\mathrm{C}_{1}$ & 1 & $0.562 * *$ & $0.582 * *$ \\
\hline$+\mathrm{C}_{2}$ & 1 & $0.096 * *$ & $0.259 * *$ \\
\hline$+\mathrm{C}_{3}$ & 1 & 0.047 & $0.074^{*}$ \\
\hline V x I & 9 & 0.001 & 0.005 \\
\hline $\mathrm{VC}_{1}$ & 3 & 0.001 & 0.011 \\
\hline $\mathrm{V} \mathrm{C}_{2}$ & 3 & 0.001 & 0.003 \\
\hline $\mathrm{V} \mathrm{C}_{4}$ & 3 & 0.001 & 0.001 \\
\hline Error "b" & 36 & 0.010 & 0.015 \\
\hline
\end{tabular}

$\mathrm{C}_{1}$ : Solid vs. intercropping faba bean plantings.

$\mathrm{C}_{2}$ : Intercropping faba bean with low density of wheat plantings vs. intercropping faba bean with both medium and high densities of wheat plantings $\left(W_{L} F_{1}\right.$ vs. $\left(W_{m} F_{1}\right.$ and $\left.W_{h} F_{1}\right)$.

$\mathrm{C}_{3}$ : Intercropping faba bean with medium density of wheat plantings vs. intercropping faba bean with high density of wheat planting $\left(\mathbf{W}_{\mathrm{m}} \mathbf{F}_{1}\right.$ vs. $\left.\mathbf{W}_{\mathrm{h}} \mathbf{F}_{1}\right)$. available environmental resources. This in turn simulated growth and photosynthetic activity of bean plants and consequently increased $\left(\mathrm{RY}_{\mathrm{f}}\right)$ trait compared with intercropping both crops with higher wheat plant density.

\subsubsection{Land Equivalent Ratio (LER)}

The analysis of variance showed that the LER was insignificantly affected by the four studied varieties in both seasons. Meanwhile, the intercropping patterns were highly significant on the LER, in both seasons (Table, 6). Regarding the monoculture $v s$. intercropping patterns $\left(\mathrm{C}_{1}\right)$, the data indicated that intercropping was significantly superior over the monoculture plantings in both seasons as shown in Table (7).The estimated values of LER for intercropping patterns were greater than one (1.40), as an average of both seasons (Table, 7). This means that, under studied conditions about $140 \%$ of land area was needed for solid wheat and faba bean to produce the same yields obtained from intercropping both crops together. Solid plantings of faba bean vs. solid plantings of wheat $\left(\mathrm{C}_{2}\right)$, indicated that solid plantings of the former significantly increased by about $19.40 \%$, as an average of both seasons, compared with the solid plantings of the latter (Tables 6 and 7). Regarding to the third comparison $\left(c_{3}\right)$, solid the latter plantings at seeding rate 300 grains $/ \mathrm{m}^{2}$ compared with the solid plantings by more seeding rates for wheat i.e., (350) and 400 grains $/ \mathrm{m}^{2}$ ), the data presented in (Table 6 and 7), revealed that solid the later plantings by higher seeding rates more than 300 grains $/ \mathrm{m}^{2}$ significantly increased the LER by about $23.74 \%$, as an average of both seasons, compared with the wheat solid plantings. With respect to the fourth comparison $\mathrm{C}_{4}$ : solid plantings of wheat seeded by 350 grains $/ \mathrm{m}^{2}$ vs. solid plantings of wheat by 400 grains $/ \mathrm{m}^{2}$, the data in Tables (6 and 7) revealed that LER insignificantly increased with increasing seeding rates in both seasons. Concerning the fifth comparison $\mathrm{C}_{5}$ : intercropped wheat with faba bean at seeding rate 300 grain $/ \mathrm{m}^{2}$ compared with intercropped wheat with faba bean by more seeding rates for wheat i.e., (350 and 400 grain $/ \mathrm{m}^{2}$ ), the data in Tables 6 and 7 showed insignificantly decreased in LER with increasing seeding rates in both seasons. With regard to the sixth comparison $\mathrm{C}_{6}$; namely, the medium density of intercropping wheat with faba bean plantings (350 grain $/ \mathrm{m}^{2}$ ) vs. the high density of intercropping wheat with faba bean plantings (400 grain $/ \mathrm{m}^{2}$ ); i.e., $\mathrm{W}_{\mathrm{m}} \mathrm{F}_{1}$ vs. $\mathrm{W}_{\mathrm{h}} \mathrm{F}_{1}$, it is clear that LER value was significantly decreased with 
Table (5): Means of relative yields of faba bean $\left(R Y_{f}\right)$ as affected by different wheat varieties $(V)$ and (wheat/ faba bean) intercropping patterns (I) in 2009/2010 and 2010/2011 seasons.

\begin{tabular}{|c|c|c|c|c|c|c|c|c|c|c|c|}
\hline \multirow{3}{*}{ 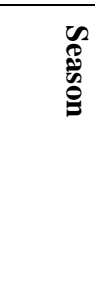 } & \multicolumn{4}{|c|}{ Wheat varieties (V) } & \multicolumn{6}{|c|}{ Cropping patterns(I) } & \multirow{3}{*}{$\begin{array}{l}3 \\
\frac{2}{3}\end{array}$} \\
\hline & Giza 168 & \multirow{2}{*}{ 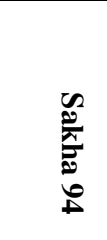 } & \multirow{2}{*}{ 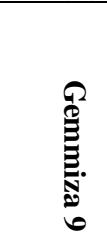 } & \multirow[t]{2}{*}{ Sids 1} & \multicolumn{2}{|c|}{$\begin{array}{c}\mathrm{C}_{1:} \text { Solid vs. } \\
\text { Intercropping faba } \\
\text { bean plantings }\end{array}$} & \multicolumn{2}{|c|}{$\begin{array}{c}\mathbf{C}_{2} ; \\
\mathrm{W}_{1} \mathbf{F}_{1} \text { vs. } \\
\left(\mathbf{W}_{\mathrm{m}} \mathbf{F}_{1} \text { and }\right. \\
\left.\mathbf{W}_{\mathrm{h}} \mathbf{F}_{1}\right)\end{array}$} & \multicolumn{2}{|c|}{$\begin{array}{c}\mathbf{C}_{3} ; \\
\left(\mathbf{W}_{\mathrm{m}} \mathbf{F}_{1} \text { vs. }\right. \\
\left.\mathbf{W}_{\mathrm{h}} \mathbf{F}_{1}\right) .\end{array}$} & \\
\hline & & & & & Solid & $\begin{array}{c}\text { Inter- } \\
\text { cropping }\end{array}$ & $\mathbf{W}_{1} \mathbf{F}_{1}$ & $\begin{array}{c}\left(\mathbf{W}_{\mathrm{m}} \mathbf{F}_{1}+\right. \\
\mathrm{W}_{\mathrm{h}} \mathbf{F}_{1}\end{array}$ & $\mathbf{W}_{\mathrm{m}} \mathbf{F}_{1}$ & $\mathbf{W}_{\mathrm{h}} \mathbf{F}_{1}$ & \\
\hline $1^{s t}$ & $0.824 \mathrm{a}^{(1)}$ & $0.846 a$ & $0.828 \mathrm{a}$ & $0.842 \mathrm{a}$ & $1.00 \mathrm{a}$ & $0.780 \mathrm{~b}$ & $0.843 \mathrm{a}$ & $0.748 b$ & $0.778 \mathrm{a}$ & $0.719 a$ & 0.835 \\
\hline $2^{\text {nd }}$ & $0.773 \mathrm{a}$ & $0.871 \mathrm{a}$ & $0.838 \mathrm{a}$ & $0.858 \mathrm{a}$ & $1.00 \mathrm{a}$ & $0.780 \mathrm{~b}$ & $0.884 a$ & $0.728 b$ & $0.776 \mathrm{a}$ & $0.679 \mathrm{~b}$ & 0.835 \\
\hline
\end{tabular}

(1)Means followed by the same letter within each row, for each comparison, are not significantly different at 0.05 level.

$\left(W_{L} F_{1} ; W_{m} F_{1}\right.$ and $\left.W_{h} F_{1}\right)=$ Intercropped faba bean with wheat at seeding rates of $\left(300,350\right.$ and 400 wheat grains $\left./ \mathbf{m}^{2}\right)$, respectively.

Table (6): Mean squares of the Land Equivalent Ratio (LER) for wheat and faba bean intercropped by different wheat varieties and cropping patterns in 2009/2010 and 2010/2011 seasons.

\begin{tabular}{|c|c|c|c|}
\hline \multirow[t]{2}{*}{ Sources of variations } & \multirow[t]{2}{*}{ D.F } & \multicolumn{2}{|c|}{ Seasons } \\
\hline & & $2009 / 2010$ & $2010 / 2011$ \\
\hline Replications & 3 & $0.234 * *$ & $1.456 * *$ \\
\hline Wheat varieties (V) & 3 & 0.044 & 0.044 \\
\hline Error "a" & 9 & 0.027 & $\mathbf{0 . 0 2 3}$ \\
\hline Cropping patterns (I) & 6 & $1.352 * *$ & $1.362 * *$ \\
\hline$+\mathrm{C}_{1}$ & 1 & $7.568 * *$ & $7.388 * *$ \\
\hline$+\mathrm{C}_{2}$ & 1 & $0.329 * *$ & $0.303 * *$ \\
\hline$+\mathrm{C}_{3}$ & 1 & 0.116* & 0.251* \\
\hline$+\mathrm{C}_{4}$ & 1 & 0.001 & 0.003 \\
\hline$+\mathrm{C}_{5}$ & 1 & 0.041 & 0.064 \\
\hline$+\mathrm{C}_{6}$ & 1 & 0.059 & 0.161* \\
\hline V x I & 18 & 0.017 & $\mathbf{0 . 0 2 4}$ \\
\hline $\mathrm{V} \mathrm{C}_{1}$ & 3 & 0.039 & 0.034 \\
\hline $\mathrm{V} \mathrm{C}_{2}$ & 3 & 0.020 & 0.025 \\
\hline $\mathrm{V} \mathrm{C}_{3}$ & 3 & 0.009 & 0.002 \\
\hline $\mathrm{V} \mathrm{C}_{4}$ & 3 & 0.019 & 0.024 \\
\hline $\mathrm{V} \mathrm{C}_{5}$ & 3 & 0.004 & 0.023 \\
\hline $\mathrm{V} \mathrm{C}_{6}$ & 3 & 0.012 & 0.035 \\
\hline Error "b" & 72 & 0.020 & $\mathbf{0 . 0 3 7}$ \\
\hline
\end{tabular}

$\mathrm{C}_{1}$ : Solid plantings vs. intercropping plantings

$\mathrm{C}_{2}$ : Solid faba bean plantings vs. solid wheat plantings.

$\mathrm{C}_{3}$ : Low density of solid wheat plantings vs. both medium and high densities of solid wheat plantings $\left[\mathrm{W}_{\mathrm{L}} \mathrm{F}_{\mathbf{0}} \mathrm{vs}\right.$. $\left(\mathrm{W}_{\mathrm{m}} \mathrm{F}_{0}\right.$ and $\left.\left.\mathrm{W}_{\mathrm{h}} \mathrm{F}_{0}\right)\right]$.

$C_{4}$ : Medium density of solid wheat plantings vs. high density of solid wheat plantings $\left(W_{m} F_{0}\right.$ vs. $\left.W_{h} F_{0}\right)$.

$C_{5}$ : Low density of intercropped wheat plantings vs. both medium and high densities of intercropped wheat plantings $\left\{W_{L} F_{1} v s\right.$. $\left(W_{\mathrm{m}} \mathbf{F}_{1}\right.$ and $\left.\mathrm{W}_{\mathrm{h}} \mathbf{F}_{1}\right)$ \}.

$\mathrm{C}_{6}$ : Medium density of intercropped wheat plantings vs. high density of intercropped wheat plantings $\left(\mathrm{W}_{\mathrm{m}} \mathrm{F}_{1}\right.$ vs. $\left.\mathrm{W}_{\mathrm{h}} \mathbf{F}_{1}\right)$.

*and ** are significant at 0.05 and 0.01 level, respectively.

increased wheat seeding rates from 350 to 400 grain $/ \mathrm{m}^{2}$ in the second season (Tables 6 and 7 ).

These results are in line with those of (ElMonufi,1984;Abd El-Gawad et al .,1986; Saleh et al .,1986 and Eid et al .,1988).

\subsection{Aggressivity}

Data in Table (8), present the values of aggressivity for wheat and faba bean crops as affected by both studied factors i.e., wheat varieties and intercropping patterns in 2009/2010 and 2010/2011 seasons. It was evident from Table (8) that the four wheat varieties were significantly different in the second season only. It is clear that the wheat Sakha 94 variety was the most aggressive compared with the other studied varieties in both seasons. In addition, the data revealed that the aggressivity values of faba bean were positive, while of wheat was negative, under the three intercropping treatments in both seasons. This means that faba bean was dominate intercrop component and wheat was the dominated at three intercropping treatments in both seasons. Similar results were reported by (El-Monufi, 1984; Saleh 
Table (7): Means of Land equivalent ratio (LER) for wheat and faba bean intercropped together as affected by different wheat varieties (V) and cropping patterns (I) in2009/2010 and 2010/2011 seasons

\begin{tabular}{|c|c|c|c|c|c|c|c|c|c|c|c|c|c|c|c|c|c|}
\hline \multirow{3}{*}{ 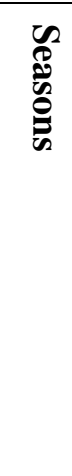 } & \multicolumn{4}{|c|}{ Wheat varieties (V) } & \multicolumn{12}{|c|}{ Comparisons among(wheat/ faba bean) cropping patterns (I) } & \multirow{3}{*}{$\frac{2}{3}$} \\
\hline & \multirow[t]{2}{*}{ Giza 168} & \multirow[t]{2}{*}{$\begin{array}{l}\text { Sakha } \\
94\end{array}$} & \multirow[t]{2}{*}{ 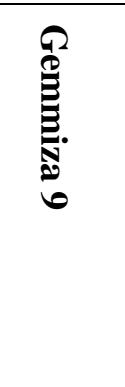 } & \multirow[t]{2}{*}{ Sids1 } & \multicolumn{2}{|c|}{$\begin{array}{l}\mathrm{C}_{1} \text {; Solid } \\
\text { plantings vs. } \\
\text { intercropping } \\
\text { plantings }\end{array}$} & \multicolumn{2}{|c|}{$\begin{array}{l}\mathrm{C}_{2} \text {; Solid faba } \\
\text { bean plantings vs. } \\
\text { solid wheat } \\
\text { plantings }\end{array}$} & \multicolumn{2}{|c|}{$\begin{array}{l}\mathbf{C}_{3} ;\left\{\mathbf{W}_{\mathrm{L}} \mathbf{F}_{\mathbf{0}} \mathbf{v s} .\right. \\
\left(\mathbf{W}_{\mathbf{m}} \mathbf{F}_{\mathbf{0}} \text { and }\right. \\
\left.\left.\mathbf{W}_{\mathbf{h}} \mathbf{F}_{0}\right)\right\}\end{array}$} & \multicolumn{2}{|c|}{$\begin{array}{l}\mathbf{C}_{4} ; \\
\left(\mathbf{W}_{\mathbf{m}} \mathbf{F}_{0}\right. \\
\left.\text { vs. } \mathbf{W}_{h} \mathbf{F}_{0}\right)\end{array}$} & \multicolumn{2}{|c|}{$\begin{array}{l}\mathbf{C}_{5} ; \\
\mathbf{W}_{\mathbf{L}} \mathbf{F}_{1} \text { vs. } \\
\left(\mathbf{W}_{\mathbf{m}} \mathbf{F}_{1} \text { and }\right. \\
\left.\mathbf{W}_{\mathbf{h}} \mathbf{F}_{1}\right)\end{array}$} & \multicolumn{2}{|c|}{$\begin{array}{l}\mathbf{C}_{6} \\
\left(\mathbf{W}_{\mathrm{m}} \mathbf{F}_{1} \mathbf{v s} .\right. \\
\left.\mathbf{W}_{\mathrm{h}} \mathbf{F}_{1}\right)\end{array}$} & \\
\hline & & & & & $\begin{array}{c}\text { Solid } \\
\text { planti } \\
\text { ngs }\end{array}$ & \begin{tabular}{|c|} 
Intercro \\
pping \\
plantings
\end{tabular} & $\begin{array}{c}\text { Solid } \\
\text { faba } \\
\text { bean } \\
\text { plantings }\end{array}$ & $\begin{array}{c}\text { Solid } \\
\text { wheat } \\
\text { plantings }\end{array}$ & $\mathbf{W}_{\mathbf{L}} \mathbf{F}_{\mathbf{0}}$ & $\begin{array}{c}\mathbf{W}_{\mathrm{m}} \mathbf{F}_{\mathbf{0}} \\
\text { and } \\
\mathbf{W}_{\mathrm{h}} \mathbf{F}_{\mathbf{0}}\end{array}$ & $\mathbf{W}_{\mathbf{m}} \mathbf{F}_{\mathbf{0}}$ & $\mathbf{W}_{\mathbf{h}} \mathbf{F}_{\mathbf{0}}$ & $\mathbf{W}_{\mathrm{L}} \mathbf{F}_{1}$ & $\begin{array}{c}\mathrm{W}_{\mathrm{m}} \mathbf{F}_{1} \\
\text { and } \\
\mathrm{W}_{\mathrm{h}} \mathbf{F}_{1}\end{array}$ & $\mathbf{W}_{\mathrm{m}} \mathbf{F}_{1}$ & $\mathbf{W}_{h} \mathbf{F}_{1}$ & \\
\hline $1^{s t}$ & $1.140 a^{(1)}$ & $1.075 a$ & $1.126 a$ & $1.063 a$ & $0.876 b$ & $1.401 a$ & $1.00 a$ & 0.834b & $0.765 b$ & $0.869 a$ & $0.865 a$ & $0.873 a$ & $1.443 a$ & $1.380 \mathrm{a}$ & $1.423 a$ & 1.338a & 1.10 \\
\hline $2^{\text {nd }}$ & $1.134 a$ & $1.096 b$ & 1.133a & $\mathbf{1 . 0 5 0 b}$ & $0.881 b$ & 1.400a & $1.00 a$ & $0.841 b$ & 0.739b & $0.992 a$ & 0.883a & $0.902 a$ & $1.451 a$ & 1.374a & $1.445 a$ & $1.303 b$ & 1.103 \\
\hline
\end{tabular}

(1)Means followed by the same letter within each row, for each comparison, are not significantly different at 0.05 level.

$\left(W_{L} F_{0} ; W_{m} F_{0}\right.$ and $\left.W_{h} F_{0}\right)=$ Sowing wheat as sole crop at rates of $\left(300,350\right.$ and 400 grains $\left./ \mathrm{m}^{2}\right)$, respectively.

$\left(W_{L} F_{1} ; W_{m} F_{1}\right.$ and $\left.W_{h} F_{1}\right)=$ Intercropped wheat with faba bean at seeding wheat by $\left(300,350\right.$ and 400 grains $\left./ \mathrm{m}^{2}\right)$, respectively. 
Table (8) : Aggressivity values for yields of wheat $\left(\mathrm{Ag}_{\mathrm{w}}\right)$ and faba bean $\left(\mathrm{Ag}_{\mathrm{f}}\right)$ as affected by wheat varieties and intercropping patterns in 2009/2010 and 2010/2011 seasons.

\begin{tabular}{|c|c|c|c|c|}
\hline \multirow[t]{2}{*}{ Studied factors } & \multicolumn{2}{|c|}{ 2009/2010 season } & \multicolumn{2}{|c|}{ 2010/2011 season } \\
\hline & $\mathbf{A g}_{\mathrm{w}}$ & $\mathbf{A g}_{\mathrm{f}}$ & $\mathbf{A g}_{\mathrm{w}}$ & $\mathbf{A g}_{\mathrm{f}}$ \\
\hline Wheat varieties (v) & & & & \\
\hline Giza 168 & -0.142 & 0.142 & -0.008 & 0.008 \\
\hline Sakha 94 & -0.234 & 0.234 & -0.271 & 0.271 \\
\hline Gemmiza 9 & -0.087 & 0.087 & -0.140 & 0.140 \\
\hline Sids 1 & -0.172 & 0.172 & -0.243 & 0.243 \\
\hline F-test & NS & NS & $*$ & $*$ \\
\hline Intercropping patterns(I) & & & & \\
\hline $\mathbf{W}_{1} \mathbf{F}_{1}$ & -0.243 & 0.243 & -0.316 & 0.316 \\
\hline $\mathbf{W}_{\mathrm{m}} \mathbf{F}_{1}$ & -0.132 & 0.132 & -0.124 & 0.124 \\
\hline $\mathbf{W}_{\mathrm{h}} \mathbf{F}_{1}$ & -0.100 & 0.100 & -0.056 & 0.056 \\
\hline F-test & NS & NS & $* *$ & $* *$ \\
\hline Interaction $(\mathbf{V x I})$ & NS & NS & NS & NS \\
\hline
\end{tabular}

$\left(W_{1} F_{1} W_{m} F_{1}\right.$ and $\left.W_{0} F_{1}\right)=$ Intercropped faba bean with wheat at seeding rates of $\left(300,350\right.$ and 400 wheat grains $\left./ \mathrm{m}^{2}\right)$, respectively. NS, * and ** are not significant, significant at 0.05 and 0.01 level, respectively.

Table (9) : Relative Crowding Coefficient values for yields of wheat $\left(\mathrm{RCC}_{\mathrm{w}}\right)$ and faba bean $\left(\mathrm{RCC}_{\mathrm{f}}\right)$ as affected by wheat varieties and intercropping patterns in $2009 / 2010$ and 2010/2011 seasons.

\begin{tabular}{|c|c|c|c|c|}
\hline & \multicolumn{2}{|c|}{$2009 / 2010$ season } & \multicolumn{2}{|c|}{ 2010/2011 season } \\
\hline & $\mathbf{R C C}_{\mathrm{w}}$ & $\mathbf{R C C}_{\mathrm{f}}$ & $\mathbf{R C C}_{\mathrm{w}}$ & $\mathbf{R C C}_{\mathrm{f}}$ \\
\hline \multicolumn{5}{|l|}{ Wheat varieties (v) } \\
\hline Giza 168 & 2.208 & 31.429 & -6.476 & -18.239 \\
\hline Sakha 94 & 1.438 & 4.489 & 19.683 & -1.513 \\
\hline Gemmiza 9 & 1.975 & 2.571 & 4.276 & 7.710 \\
\hline Sids 1 & 2.050 & -1.773 & 4.292 & 10.288 \\
\hline F-test & NS & NS & NS & NS \\
\hline Intercropping patterns(I) & & & & \\
\hline $\mathbf{W}_{1} \mathbf{F}_{1}$ & 1.801 & 7.516 & 0.412 & 11.486 \\
\hline $\mathbf{W}_{\mathrm{m}} \mathbf{F}_{1}$ & 2.659 & 24.845 & 2.509 & 7.552 \\
\hline $\mathbf{W}_{\mathrm{h}} \mathbf{F}_{1}$ & 1.293 & -4.824 & 13.410 & 2.619 \\
\hline F-test & NS & NS & NS & NS \\
\hline Interaction(VxI) & NS & NS & NS & NS \\
\hline
\end{tabular}

$\left(W_{L} F_{1} W_{m} F_{1}\right.$ and $\left.W_{0} F_{1}\right)=$ Intercropped faba bean with wheat at seeding rates of $\left(300,350\right.$ and 400 wheat grains $\left./ \mathrm{m}^{2}\right)$, respectively $\mathrm{NS}=$ not significant at 0.05 level.

et al., 1986; Eid et al., 1988 and El-Metwally et al., 2002).

\subsection{Relative Crowding Coefficient (RCC)}

As shown in Table (9), the data indicated that wheat and faba bean Relative Crowding Coefficient (RCC) was not significantly affected by wheat varieties, in both seasons. It was clear that, higher values of $\mathrm{RCC}_{\mathrm{w}}$ were reported by Giza 168 wheat variety،, meanwhile, the lowest $\mathrm{RCC}_{\mathrm{f}}$ values were reported by Sids 1 variety in both seasons. It was evident that intercropped faba bean with wheat seeded by $350 \mathrm{grain} / \mathrm{m}^{2}$ produced the higher values of RCC for wheat in both seasons. Meanwhile, intercropped faba bean with wheat seeded at rates of 400 and 300 wheat grain/ $\mathrm{m}^{2}$ produced the higher values of RCC for faba bean in the first and second seasons, respectively (Table 9).

In general, it could be concluded that intercropping any studied wheat variety seedling by 300 grain $/ \mathrm{m}^{2}$ with Sakha 1 faba bean cultivar at 166667 plant/ ha in alternative rows $20 \mathrm{~cm}$ apart (1:1) could be recommended to maximize the productivity of land unit area under sandy soil conditions, in El-Bostan Region, El- Behera Governorate, Egypt.

4.Effect of the interaction between wheat varieties and cropping patterns: 
Table (10): Means of relative yields for wheat $\left(R Y_{w}\right)$ intercropped with faba bean as affected by the wheat varieties and intercropping patterns $\left(\mathrm{VxC}_{1}\right)$ in $2009 / 2010$ season.

\begin{tabular}{|l|c|c|c|c|}
\hline \multirow{2}{*}{$\begin{array}{c}\text { C Solid wheat plantings } \\
\text { intercropping wheat plantings }\end{array}$} & \multicolumn{4}{|c|}{ Wheat varieties (V) } \\
\cline { 2 - 5 } : Giza 168 & Sakha 94 & Gemmiza 9 & Sids 1 \\
\hline Solid wheat plantings & 0.937 & 0.821 & 0.841 & 0.739 \\
\hline Intercropping wheat plantings & 0.624 & 0.560 & 0.683 & 0.618 \\
\hline $\begin{array}{l}\text { L.S.D } \\
\text { the same } \text { for the two levels of (I) under }\end{array}$ & \multicolumn{3}{|c|}{0.140} \\
\hline
\end{tabular}

There was a significant effect for the interaction between wheat varieties and first comparison $\left(\mathrm{C}_{1}\right)$, namely, solid wheat plantings vs. intercropping wheat plantings, for the relative yield of wheat, in the $1^{\text {st }}$ season as shown in Table(2). The data show that the highest mean relative yield of wheat was obtained by solid plantings of wheat under wheat variety Giza 168 , while, the lowest mean relative yield of wheat was obtained by intercropping plantings under wheat variety Sakha 94 (Table 10).

\section{REFERENCES}

Abd El-Gawad A.A., Edris A.S. and Abo-Shetaia A.M.(1988). Intercropping faba bean with wheat.3- Inter - and intraspeceific competition among faba bean and wheat plants. Annals Agric. Sci., Fac.Agric., Ain Shams Univ., 33(2): 1015-1029.

Abd El-Gawad A.A., El -Tabbakh A.E., Edris A.S. and Abo-Shetaia A.M. (1986).Potential productivity of wheat in Egypt.VIII. Effect of seeding rates on yield and its components. Annals Agric. Sci., Fac.Agric, Ain Shams Univ., 31(2):1173- 1182.

Ali A.A.M., Mosaad M.G., Dawla N.F. and Kalifa M.M. (1986). Feasibility of intercropping wheat (T. durum Deaf.) with faba bean (Vicia faba L.) under different culture practices. Annals of Agric. Sci., Moshtohor, 24(2):727-747.

Eid H.M., Ainer .G. and Metwally M.A. (1988). Studies on intercropping wheat with faba bean.
Egypt. J. Soil Sci. 28(1): 91-102.

El-Metwally A.E., El-Murshedy W.A. and Mahmoud G.O. (2002). Productivity of wheat and faba bean under different intercropping systems. J.Agric. Res.,Tanta Univ. 28(2):312326.

El-Monufi M.M. (1984). Studies on intercropping wheat with various crops. Ph.D Thesis, Fac. Agric., Al-Azhar Univ., Egypt.

McGilchrist C.A. (1965). Analysis of competition experiments. Biometrics, 21:975-1985 (Cited after, Willey, 1979).

Piper C.S. (1950).Soil and Plant Analysis. Interscience Publishers Inc., New York, pp.151- 172,USA.

Saleh M.E., Ali A.A.G. and Ramadan I.E. (1986).Yield and yield components of intercropped wheat faba bean in various intercropping systems. Agron.Alex., Egypt (1): 635-647.(cited after, El-Metwally et al.,2002).

Steel R.G.D. and Torrie I. N. (1980). Principles and Procedures of Statistics $2^{\text {nd }}$ Edition. Mc. Graw Hill Co, New York, USA.

Willey R.W. (1979). "Intercropping", its importance and research need. Part.1Competition and yield advantages. Field Crop Abst., 32:1-10.

Willey R.W. and Osera S.O. (1972). Studies on mixture of maize and beans (Phaseolus vulgaris) with particular reference to plant population. J.Agric. Sci. Cambridge, 79:519529.

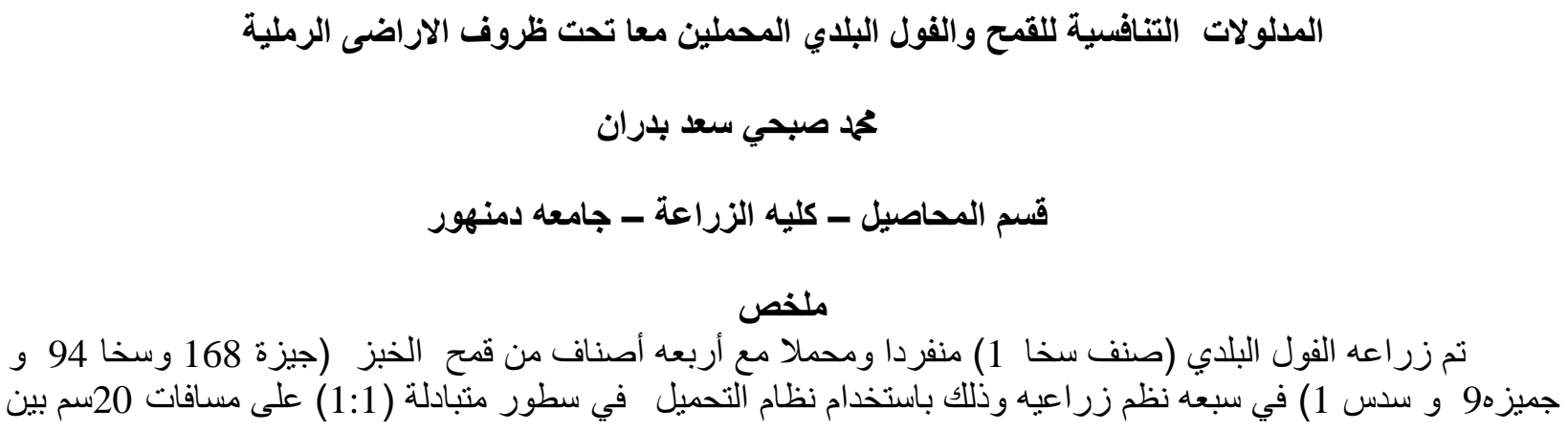




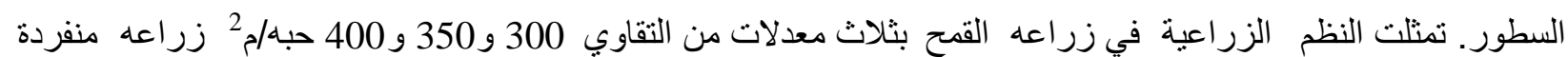

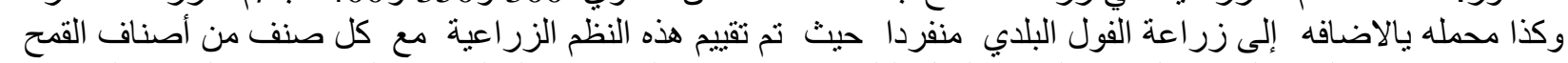

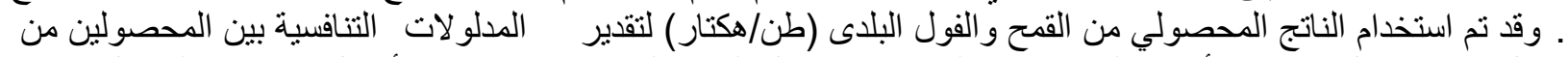

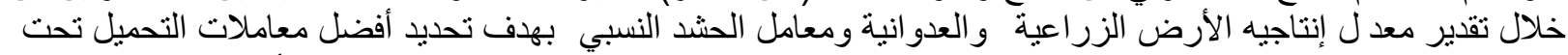

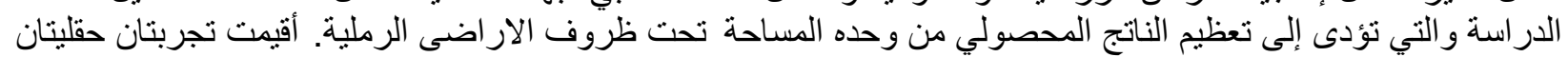

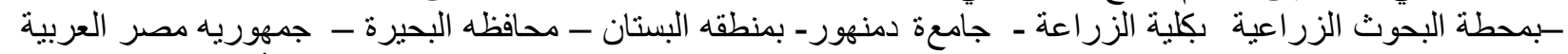

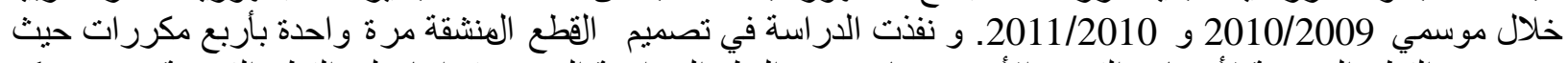

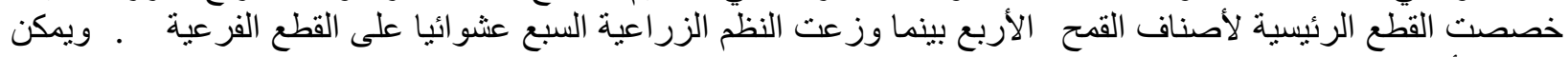

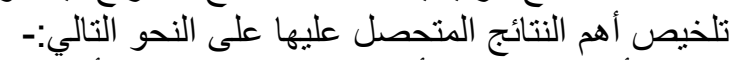

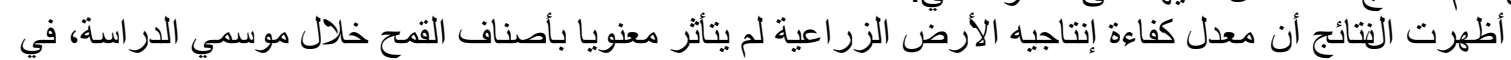

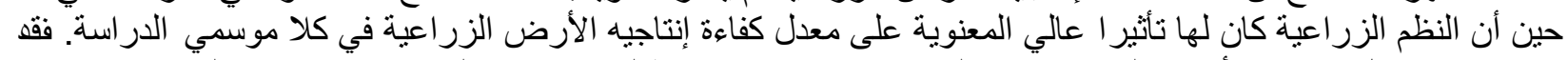

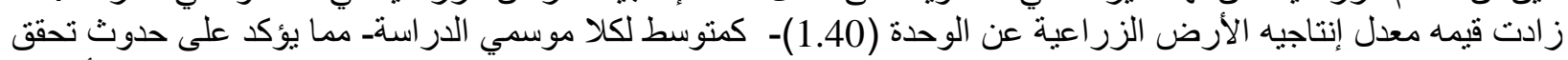

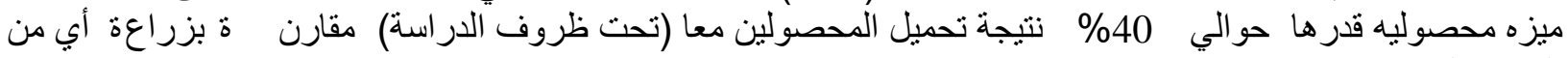

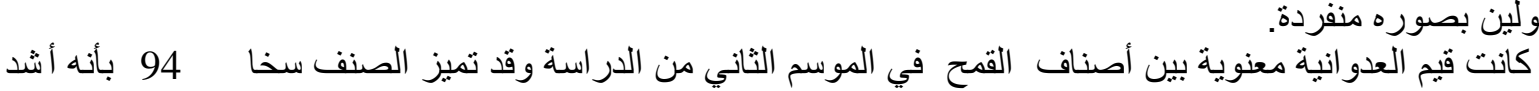

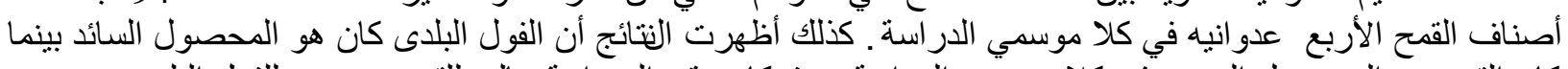

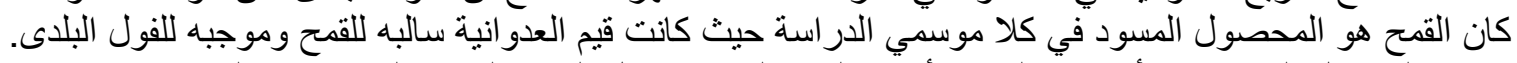

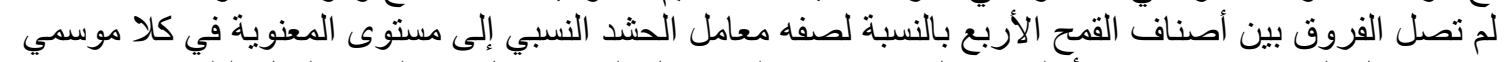

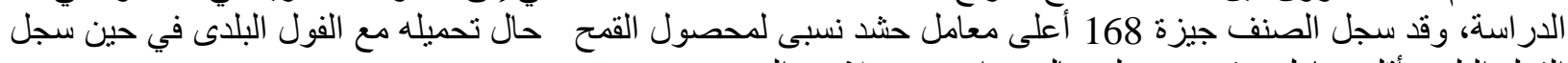

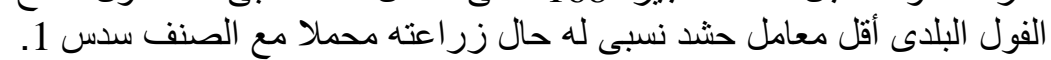

كان التفاعل بين أصناف القمح و النظم الزر اعية معنويا فقط بالنسبة لصفة الإنتاجية النسبية لمحصول القمح (فى الموسم الأول).

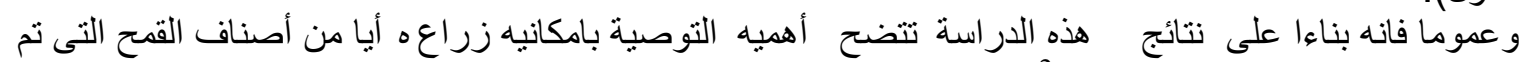

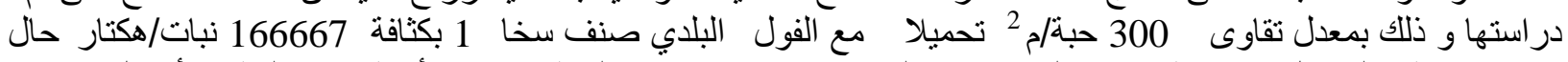

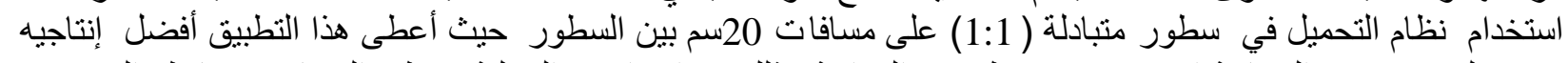

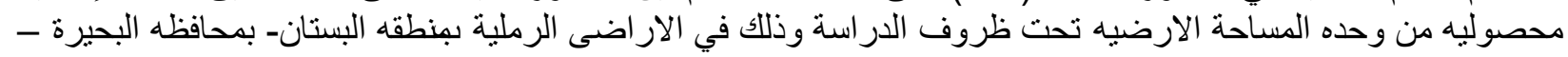
جمهوريه مصر العربية. المجلة العلمية لكلية الزراعة - جامعة القاهرة - المجلا (62) العدد الثالث (يوليو 2011):302-293. 